\title{
Chemical Composition and Antioxidant DPPH Activity of the Floral and Leaves Essential Oils of Montanoa speciosa DC
}

\author{
Durcy Ruiz-Ciau1, Luis Cuevas-Glory², Leovigildo Quijano3, Enrique Sauri-Duch² \\ ${ }^{1}$ Facultad de Química, Universidad Autónoma de Yucatán, Mérida, México \\ ${ }^{2}$ División de Estudios de Posgrado e Investigación, Departamento de Ingeniería Química y Bioquímica del Instituto Tecnológico \\ de Mérida, Tecnológico Nacional de México, Km. 5 Carr. Mérida-Progreso, Mérida, México \\ ${ }^{3}$ Facultad de Química, Universidad Nacional Autónoma de México, Mérida, México \\ Email: esauri5@yahoo.com.mx
}

How to cite this paper: Ruiz-Ciau, D., Cuevas-Glory, L., Quijano, L. and SauriDuch, E. (2017) Chemical Composition and Antioxidant DPPH Activity of the Floral and Leaves Essential Oils of Montanoa speciosa DC. American Journal of Plant Sciences, 8, 745-753. https://doi.org/10.4236/ajps.2017.84052

Received: April 28, 2016

Accepted: March 17, 2017

Published: March 20, 2017

Copyright ( $) 2017$ by authors and Scientific Research Publishing Inc. This work is licensed under the Creative Commons Attribution International License (CC BY 4.0).

http://creativecommons.org/licenses/by/4.0/ (c) (i) Open Access

\begin{abstract}
The essential oils obtained by hydrodistillation from leaves and flowers of Montanoa speciosa collected in southeastern Mexico (Yucatan) were analyzed by GC-MS. A total of 71 and 79 components, representing $98.44 \%$ and $97.69 \%$ of the leaf and flower oils, respectively, were characterized. The main constituents found were $\beta$-caryophyllene (20.73\%, 17.95\%), $\delta$-cadinene $(9.88 \%, 9.28 \%)$, caryophyllene oxide $(9.48 \%, 8.68 \%)$, and germacrene D $(6.94 \%, 5.85 \%)$. The essential oils were screened for their antioxidant potentials by DPPH assay. The leaves oil exhibited higher DPPH scavenging capability $(72.85 \pm 0.28$ $\mathrm{mmol} \mathrm{TE} / \mathrm{g}$ essential oil and $147.83 \pm 0.41 \mathrm{mg} / \mathrm{mL}$ Vit C/g essential oil) than the floral oil $(68.43 \pm 0.10 \mathrm{mmol} \mathrm{TE} / \mathrm{g}$ essential oil and $131.59 \pm 0.87 \mathrm{mg} / \mathrm{mL}$ Vit C/g essential oil).
\end{abstract}

\section{Keywords}

Montanoa speciosa, Asteraceae, Essential Oil Composition, DPPH Assay

\section{Introduction}

Recent investigations in the field of antioxidants have focused on naturally occurring molecules to satisfy consumer concerns over safety and toxicity of food additives [1]. Antioxidants are both natural and synthetic compounds, able to scavenge free radicals and to inhibit oxidation processes [2]. Although, it was reported that synthetic antioxidants such as butyl hydroxytoluene (BHT), butyl hydroxyanisole (BHA), propyl gallate (PG), and tertiary butyl hydroquinone (TBHQ) have harmful effects in addition to their beneficial effects on food and 
health [3]. A great number of aromatic, spicy, and medicinal plants contain chemical compounds, with antioxidant properties [4]. The antioxidant activity of plant extracts and essential oils is of particular interest because of their beneficial physiological activity on human cells and the potential they have to replace synthetic antioxidants used in foodstuffs [5] [6].

The Montanoa genus is one of the largest genuses belonging to the Asteraceae family. In México, there are 35 native species from this genus [7] [8]. Several species are of importance since they have been used in traditional medicine as abortive (Montanoa tomentosa, M. grandiflora, M. frutescens) and ornamental plants (M. hibiscifolia, M. grandiflora) [9] [10]. M. tomentosa known as "zoapatle" is a valued species due to its medicinal properties, mainly as a menstruation and childbirth inducer [11] [12].

Montanoa speciosa D. C., a species found in Yucatan, is a shrub about $2 \mathrm{~m}$ in height, with leaves and flowers very fragrant.

There are few reports concerning Montanoa essential oils. A study determined the chemical composition of essential oil from aerial parts of Montanoa tomentosa by SPME-GC-MS [13]. Another study assumes that the possible abortifacient activity is related to the chemical composition of essential oil from Montanoa tomentosa [14].

In this work, we describe, for the first time, the essential oil composition of Montanoa speciosa leaves and flowers using GC-MS and its antioxidant activity, evaluated with 2,2-diphenyl-1-picrylhydrazyl (DPPH) assay.

\section{Material and Methods}

\subsection{Plant Material}

Leaves and flowers of Montanoa speciosa DC (Asteraceae), were collected from a cultivated ornamental specimen in Merida, in the state of Yucatan, Mexico, in August and November of 2009, in the rainy season and flowering, respectively. The botanical identification of the specie was performed for one of the authors (L. Quijano).

\subsection{Isolation of the Essential Oils}

Dry leaves and flowers (50 g each one) of M. speciosa (Figure 1) were cut in small pieces and submitted to hydrodistillation for $4 \mathrm{~h}$, using a Clevenger-type apparatus. The oils were decanted and dried over anhydrous sodium sulphate.

The oil yield (calculated as oil w/w of dry extract) of leaf oil was $0.19 \%$, and the floral oil was $0.59 \%$. The oils were stored at $4^{\circ} \mathrm{C}$ until their analysis.

\subsection{Essential Oil Gas Chromatography-Mass Spectrometry Analysis}

The oil samples were analyzed by gas chromatography-mass spectrometry, using Agilent technologies 6890 GC interfaced with a quadrupole mass spectrometer system 5973, and an Agilent Chemstation data system. The GC column was an HP-5MS fused silica capillary with a (5\% phenyl)-methylpolysiloxane 


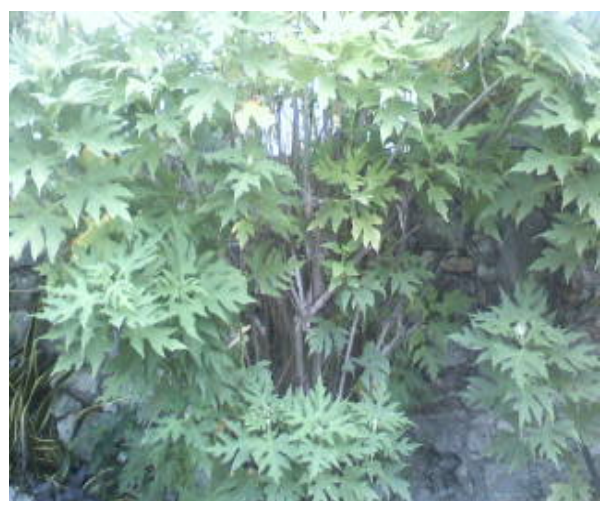

(a)

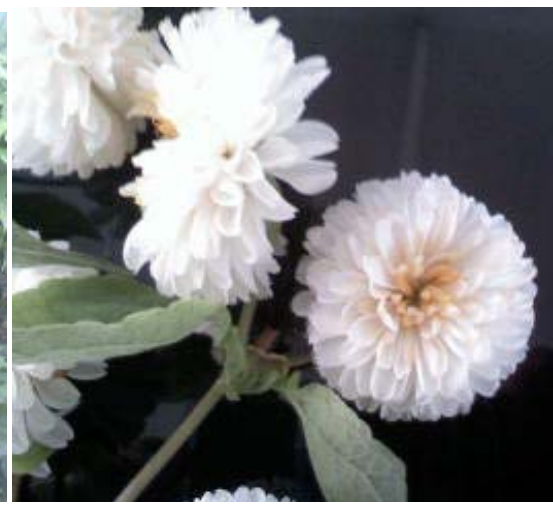

(b)

Figure 1. Leaves and flowers of Montanoa speciosa. (a) leaves; (b) flowers.

stationary phase ( $30 \mathrm{~m} \times 0.25 \mu \mathrm{m}$ d. i., $0.25 \mu \mathrm{m}$ film thickness).

Inlet temperature and MSD detector temperatures were set at $270^{\circ} \mathrm{C}$ and $290^{\circ} \mathrm{C}$, respectively. The GC oven temperature program was used as follows: from $60^{\circ} \mathrm{C}$ - $246^{\circ} \mathrm{C}$ at $3^{\circ} \mathrm{C} / \mathrm{min}$ and helium was employed as carrier gas $(1 \mathrm{~mL} / \mathrm{min})$. The sample was dissolved in ethyl ether to give a $1 \% \mathrm{v} / \mathrm{v}$ solution. Injection size $1 \mu \mathrm{L}$ using a split injection technique (split ratio 20:1) were used. MS were taken at 70 $\mathrm{eV}$ with mass range of $\mathrm{m} / \mathrm{z} 41-300$. Tetradecane (C14) as inner standard was used.

Identification of the components was achieved based on their lineal retention indices (KI, determined with reference to a homologous series to $\mathrm{C}_{8}{ }^{-} \mathrm{C}_{20} n$-alkanes) and by comparison of their mass spectral fragmentation patterns [NIST database (G1036A, revision D.01.00)/ChemStation data system (G1701CA, version C.00.01.08)] and comparing with literature data [15].

\subsection{Determination of Antioxidant DPPH Activity}

Radical scavenging activity of plant essential oils against to stable DPPH radical was determined spectrophotometrically [16] [17]. The colorimetric changes (from deep-violet to light-yellow) when DPPH is reduced chemically, were measured at $517 \mathrm{~nm}$ on a UV/visible light spectrophotometer. The antioxidant activities of the essential oils were measured in terms of hydrogen donation or radical scavenging ability (RSA).

Antioxidant capacity was expressed as the activity equivalent of two antioxidant compounds of reference Trolox and vitamin C. Calibration curve of DPPH solution $(0.02 \mathrm{mg} / \mathrm{mL})$ in methanol was performed to quantify the antioxidant activity of essential oil equivalent to Trolox $(0.01$ to $0.7 \mu \mathrm{g} / \mathrm{mL})$ and vitamin $\mathrm{C}$ $(01-20 \mu \mathrm{g} / \mathrm{mL})$. Regression equation for each standard compound (Trolox and vitamin $\mathrm{C})$ was calculated $\left([\mathrm{DPPH}]=\left(\mathrm{a} \times \mathrm{Abs}_{517}\right)+\mathrm{b}\right)$ to determine the equivalent concentration of each one. The absorbance of the solutions corresponding to each standard is read at a wavelength of $517 \mathrm{~nm}$.

A volume of $750 \mu \mathrm{L}$ of a methanolic solution $(0.02 \mathrm{mg} / \mathrm{mL})$ of essential oils were put into appropriate tubes, and $1.5 \mathrm{~mL}$ of $20 \mathrm{ppm}$ methanolic solution of DPPH was added to each tube. Tests were carried out in triplicate. The decrease 
in absorbance at $517 \mathrm{~nm}$ was determined after $15 \mathrm{~min}$ for all samples using a Perkin Elmer Lambda 11 spectrophotometer. Methanol was used to zero the spectrophotometer. Absorbance of the DPPH radical without antioxidant, i.e. the control, was measured.

Results are expressed in equivalent to the both standards used in the calibration activity (Trolox and vitamin C).

The radical scavenging capture percentage (\% RSC) of the DPPH radical of each essential oil was calculated according to the formula [18]:

$$
\% \operatorname{RSC}=\left(\frac{A c-A s}{A c}\right) * 100
$$

where \% RSC = DPPH inhibition (\%), $A c=$ absorbance of control sample and $A s=$ Absorbance of a tested sample.

\section{Results and Discussion}

Simple hydrodistillation of $M$. speciosa leaves and flowers produced a clear, colorless to pale yellow oils, with strong odor to wood.

The essential oils were analyzed by GC/MS for determination of their components and results are given in Table 1 as a relative peak area of each constituent and their lineal retention index (LRI) values obtained on a HP-5MS capillary column. Typical GC chromatograms are presented in Figure 2 and Figure 3.

In the essential oil from leaves 71 compounds were identified, corresponding to $98.4 \%$, containing $93.4 \%$ of terpene derivates $(5.4 \%$ and $88 \%$, monoterpenes and sesquiterpenes, respectively). Sesquiterpenes hydrocarbons (60\%) were prevalent to oxygenated sesquiterpenes (28.1\%). Moreover among monoterpenes the hydrocarbonated species were also detected in a higher percentage $(62.7 \%)$ than oxygenated (30.6\%) (Table 2). The main constituents in Montanoa speciosa leaves essential oil were $\beta$-caryophyllene (20.7\%), caryophyllene oxide (9.5\%), germacrene D (6.9\%), $\alpha$-copaene (3.9\%) and $\delta$-selinene (3.7\%).

In the essential oils of flowers, 79 compounds were identified. The monoterpenes constituted $10 \%$ and the sesquiterpenes constituted $84 \%$, of which the hydrocarbonated sesquiterpenes had the most important contributions (54.4\%). $\beta$-caryophyllene (17.9\%), caryophyllene oxide (8.7\%), germacrene D (5.8\%), $\alpha$-copaene (3.6\%), $\delta$-selinene (3.5\%) and $\alpha$-pinene (3.4\%) were the major compounds in flowers essential oils.

The essential oils of $M$. speciosa showed that the major component was $\beta$-caryophyllene, being different with literature reports on the essential oils of the other Montanoa species in which the main compounds were monoterpenes [13] [19]. However, climatic, geographic conditions, environmental factors, vegetative cycle stage and type of extraction are among the reasons that could explain such differences [20].

Antioxidant activity of essential oils extracted by hydrodistillation from leaves and flowers of $M$. speciosa has been determined by one test system, namely, the DPPH assays. All data are presented in Table 3.

In the DPPH assay, the ability of the investigated essential oils to act as donors 
Table 1. Chemical composition of floral and leaf essential oils from Montanoa speciosa.

\begin{tabular}{|c|c|c|c|c|c|c|c|c|c|}
\hline Compound & $\mathrm{LRI}^{\mathrm{a}}$ & $\mathrm{LRI}^{\mathrm{b}}$ & $\begin{array}{l}\text { Flower } \\
\text { Area\% }\end{array}$ & $\begin{array}{c}\text { Leaf } \\
\text { Area\% }\end{array}$ & Compound & $\mathrm{LRI}^{\mathrm{a}}$ & $\mathrm{LRI}^{\mathrm{b}}$ & $\begin{array}{l}\text { Flower } \\
\text { Area\% }\end{array}$ & $\begin{array}{c}\text { Leaf } \\
\text { Area } \\
\%\end{array}$ \\
\hline Triciclene & 903 & 921 & 0.1 & $\operatorname{tr}^{\mathrm{c}}$ & $\beta$-Guaiene & 1507 & 1502 & 1.9 & 2.0 \\
\hline$\alpha$-Pinene & 914 & 932 & 3.4 & 1.6 & $\alpha$-Farnesene & 1513 & 1505 & 0.1 & 0.1 \\
\hline Camphene & 931 & 946 & 1.5 & 0.8 & Germacrene A & 1515 & 1508 & 0.5 & 0.5 \\
\hline Sabinene & 966 & 969 & $\operatorname{tr}$ & $-{ }^{d}$ & $\delta$-Cadinene & 1532 & 1522 & 9.3 & 9.9 \\
\hline$\beta$-Pinene & 971 & 974 & 0.5 & 0.3 & $\alpha$-Cadinene & 1540 & 1537 & 0.2 & 0.2 \\
\hline (E)-3-Octen-2-ol & 977 & 982 & 0.2 & 0.2 & $\alpha$-Calacorene & 1546 & 1544 & 0.1 & 0.1 \\
\hline $\mathrm{NI}^{\mathrm{e}}$ & 994 & & 0.1 & 0.1 & Selin-3,7(11)-diene & 1551 & 1545 & 0.7 & 0.5 \\
\hline$p$-Cymene & 1022 & 1022 & 0.1 & - & Elemol & 1559 & 1548 & 0.4 & 0.4 \\
\hline Limonene & 1024 & 1024 & 0.1 & 0.1 & Germacrene B & 1562 & 1559 & 0.2 & 0.3 \\
\hline 1,8-Cineol & 1024 & 1026 & 0.4 & 0.3 & (E)-Nerolidol & 1568 & 1561 & 0.1 & - \\
\hline cis-Sabinene hydrate & 1057 & 1065 & $\operatorname{tr}$ & $\operatorname{tr}$ & Longipinanol & 1576 & 1567 & 0.2 & 0.2 \\
\hline Linalool & 1086 & 1095 & $\operatorname{tr}$ & $\operatorname{tr}$ & Germacren-D-4-ol & 1581 & 1574 & 0.2 & 0.2 \\
\hline trans-Pinocarveol & 1132 & 1135 & 0.1 & 0.2 & Spathulenol & 1587 & 1577 & 2.3 & 2.0 \\
\hline Camphor & 1151 & 1141 & 1.6 & 1.7 & Caryophyllene oxide & 1592 & 1582 & 8.7 & 9.5 \\
\hline Borneol & 1165 & 1165 & 0.2 & 0.2 & Globulol & 1603 & 1590 & 0.6 & 0.8 \\
\hline 4-Terpineol & 1178 & 1174 & 0.2 & 0.2 & Viridiflorol & 1605 & 1592 & 0.8 & 0.7 \\
\hline$\alpha$-Terpineol & 1184 & 1186 & $\operatorname{tr}$ & - & Carotol & 1614 & 1594 & 0.2 & - \\
\hline Bornyl acetate & 1281 & 1284 & 1.7 & 1.7 & Guaiol & 1616 & 1600 & 0.4 & 0.3 \\
\hline$\alpha$-Cubebene & 1349 & 1345 & 0.3 & 0.3 & Humulen-2-epóxide & 1619 & 1608 & 0.4 & 0.5 \\
\hline$\alpha$-Ylangene & 1368 & 1373 & 0.3 & 0.3 & $\beta$-Himanchalene oxide & 1622 & 1615 & 0.6 & 0.6 \\
\hline Isoledene & 1376 & 1374 & 0.1 & 0.1 & NI & 1624 & & 0.2 & - \\
\hline$\alpha$-Copaene & 1378 & 1374 & 3.6 & 3.8 & Dill apiole & 1627 & 1620 & 0.2 & 0.2 \\
\hline$\beta$-Cubebene & 1384 & 1387 & 0.1 & 0.1 & 1-epi-Cubenol & 1632 & 1627 & 0.4 & 0.4 \\
\hline$\beta$-Bourbonene & 1386 & 1387 & 0.3 & 0.4 & $\alpha$-Acorenol & 1638 & 1632 & 0.3 & 0.2 \\
\hline$\beta$-Elemene & 1392 & 1389 & 0.1 & 0.2 & cis-Cadin-4-en-7-ol & 1643 & 1635 & 1.8 & 1.8 \\
\hline$\beta$-Isocomene & 1395 & 1407 & 0.5 & 0.8 & $\beta$-Acorenol & 1649 & 1636 & 0.7 & 0.6 \\
\hline z-Caryophyllene & 1397 & 1408 & 0.1 & 0.2 & epi- $\alpha$-Cadinol & 1651 & 1638 & 0.9 & 0.6 \\
\hline$\alpha$-Cedrene & 1414 & 1410 & 0.2 & 0.3 & $\begin{array}{l}\text { Caryophylla-4 (12), } \\
\text { 8(13)-dien-5 } \alpha \text {-ol }\end{array}$ & 1654 & 1639 & 1.3 & 1.2 \\
\hline$\beta$-Caryophyllene & 1416 & 1417 & 17.9 & 20.7 & $\begin{array}{l}\text { allo-Aromadendrene } \\
\text { epoxide }\end{array}$ & 1657 & 1639 & 1.5 & 1.2 \\
\hline NI & 1427 & & 0.3 & 0.3 & epi- $\alpha$-Muurolol & 1665 & 1640 & 2.3 & 2.5 \\
\hline cis-Muurola-3,5-diene & 1449 & 1448 & 0.5 & 0.5 & Cubenol & 1668 & 1645 & 1.4 & 2.1 \\
\hline (E)- $\beta$-Farnesene & 1452 & 1454 & 1.6 & 1.6 & $\beta$-Eudesmol & 1670 & 1649 & 0.6 & - \\
\hline allo-Aromadendrene & 1460 & 1458 & 0.4 & 0.3 & $\alpha$-Eudesmol & 1673 & 1652 & 1.7 & 0.9 \\
\hline $\begin{array}{l}\text { trans-Cadina-1(6), } \\
\text { 4-diene }\end{array}$ & 1471 & 1475 & 0.2 & 0.27 & trans-Calamenen-10-ol & 1684 & 1668 & 0.4 & 0.5 \\
\hline$\gamma$-Gurjunene & 1477 & 1475 & 0.4 & 0.3 & $\begin{array}{c}\text { 9-epi- }(E) \text {-caryophyllene- } \\
\text { 14-hydroxide }\end{array}$ & 1686 & 1668 & 0.9 & 0.5 \\
\hline$\gamma$-Muurolene & 1480 & 1478 & 1.0 & 0.9 & trans- $\alpha$-Bergamotol & 0.4 & 0.3 & 1695 & 1690 \\
\hline Germacrene D & 1485 & 1484 & 5.8 & 6.9 & Farnesol & 0.3 & 0.3 & 1700 & 1698 \\
\hline Aristolochene & 1488 & 1487 & 2.4 & 2.7 & NI & 0.3 & 0.3 & 1705 & \\
\hline$\beta$-Selinene & 1496 & 1489 & 1.1 & 1.2 & NI & 0.6 & 0.3 & 1778 & \\
\hline$\delta$-Selinene & 1499 & 1492 & 3.5 & 3.7 & & & & & \\
\hline
\end{tabular}

${ }^{\mathrm{a}}$ LRI determined experimentally. ${ }^{\mathrm{b}} \mathrm{LRI}$ from reference. ${ }^{\mathrm{C}}$ Trace $(<0.1 \%) .{ }^{\mathrm{d}}$ Not present. ${ }^{\mathrm{e}}$ Unidentified. 


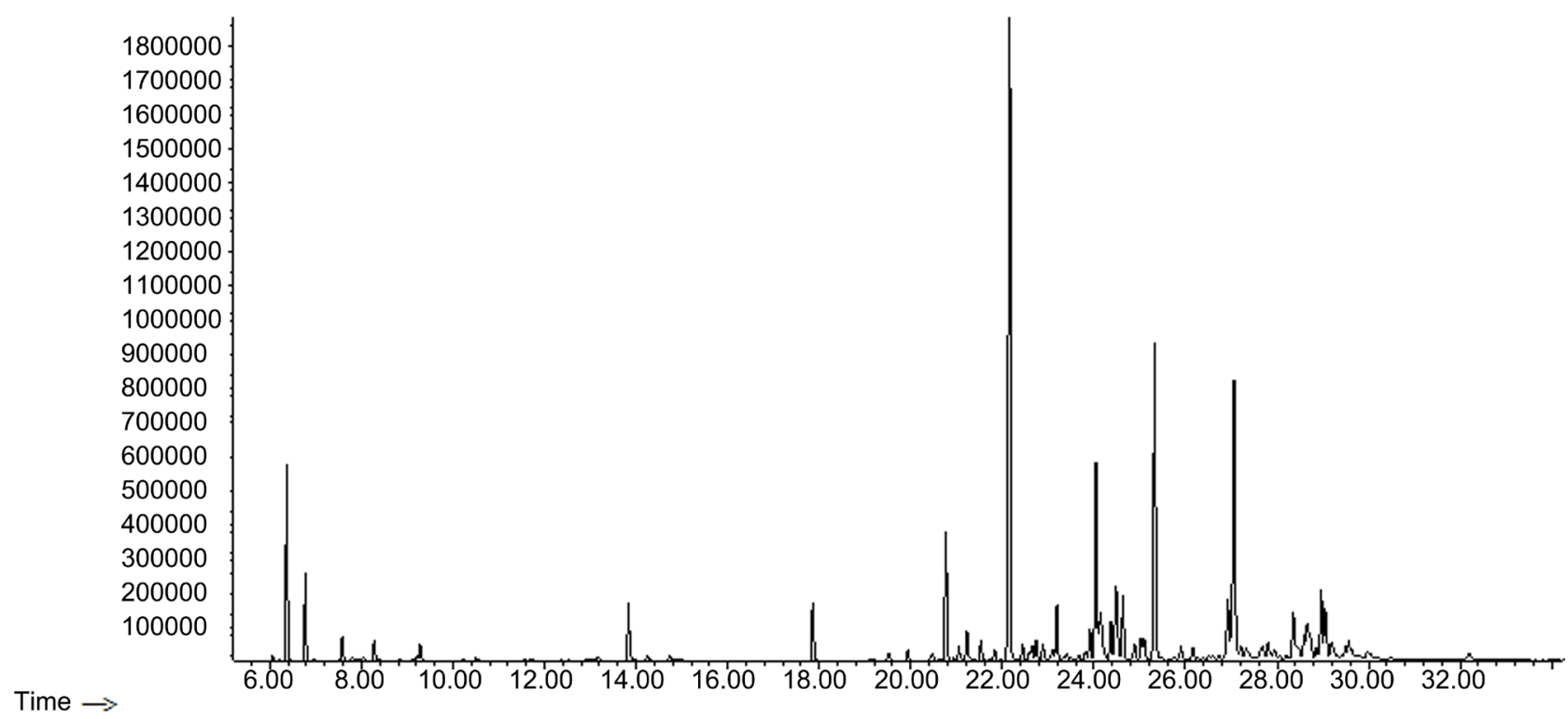

Figure 2. Typical GC chromatogram of essential oil of leaves of Montanoa speciosa.

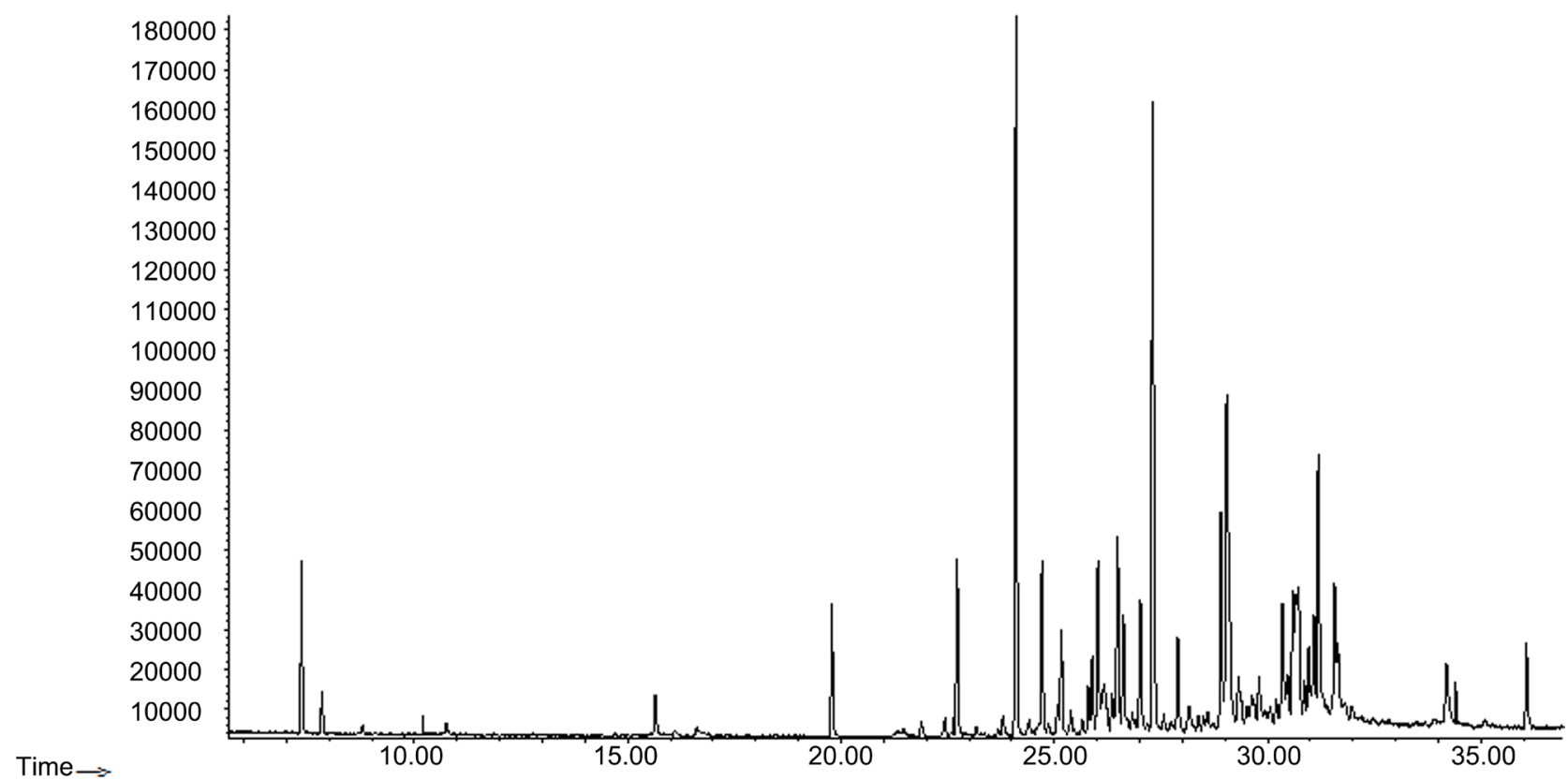

Figure 3. Typical GC chromatogram of essential oil of flowers of Montanoa speciosa.

Table 2. Area \% of types of terpenes identified in essentials oil of leaves and flowers of Montanoa speciosa.

\begin{tabular}{ccc}
\hline Grouped components & Leaf essential oil (\%) & Floral essential oil (\%) \\
\hline Monoterpene hydrocarbons & 2.8 & 5.6 \\
Oxygen-containing monoterpenes & 2.6 & 4.4 \\
Sesquiterpene hydrocarbons & 59.9 & 54.4 \\
Oxygen-containing sesquiterpenes & 28.0 & 29.6 \\
Others & 3.2 & 3.6 \\
\hline
\end{tabular}


Table 3. Radical scavenging capture percentage (\% RSC) of M. speciosa essential oils and Vit $\mathrm{C}$ and Trolox.

\begin{tabular}{cc}
\hline Sample $^{\mathbf{a}}$ & \% RSC \\
\hline Leaves & $65.4170 \pm 0.193$ \\
flowers & $61.3616 \pm 0.061$ \\
Vit C & $97.5317 \pm 0.059$ \\
Trolox & $41.1212 \pm 0.597$
\end{tabular}

${ }^{\mathrm{a} C o n c e n t r a t i o n s: ~ V i t a m i n ~ C ~} 20$ ppm, Trolox $50 \mathrm{ppm}$ and essential oils $40 \mathrm{ppm}$.

of hydrogen atoms or electrons in transformation of DPPH into its reduced form DPPH-H was investigated. All of the assessed essential oils were able to reduce the stable, purple-colored radical DPPH to yellow colored DPPH-H.

According to DPPH assay the essential oils of the two parts of $M$. speciosa showed moderate radical scavenging capture percentage (\% RSC) respect to vitamin C, but a greater activity compared with Trolox. The essential oil of leaves showed higher activity compared with the floral essential oil.

The antioxidant capacity expressed in terms of equivalent of Trolox (TE) and vitamin $\mathrm{C}$, is showed in Table 4 .

As showed, the antioxidant capacity of the leaves essential oil presented an activity slightly higher than the flowers essential oils.

There are not previous reports about \% RSC or antioxidant capacity of Montanoa speciosa, or other Montanoa species essential oils.

In literature revised there are no reports related to the chemical composition of the essential oils of Montanoa speciosa DC, however, there are reports of the study of the essential oils of Montanoa tomentosa, a plant used by indigenous populations in the center of the country as an abortifacient. Compadre et al. [14] performed the GC-MS analysis of the leaves and found that the major compounds were bornyl acetate, $\beta$-cubebene and $\beta$-caryophyllene. While, Robles et al. [13] performed the analysis of the chemical composition of leaves and flowers of Montanoa tomentosa by SPME-CG-EM and found in both cases that more than $65 \%$ of the compounds belong to the monoterpene series, being the compounds sabinene, $\alpha$-pinene and $\alpha$-thujene, the majority; In contrast to what was observed in this study. From Montanoa speciosa there are reports of biological activity and structural elucidation of sesquiterpene lactones obtained from the aerial parts of this plant [21], Sabanero et al. [22], Quijano et al. [23].

\section{Conclusion}

In the present investigation, chemical composition and scavenging activity with DPPH assay of essential oils of dry leaves and flowers of $M$. speciosa were evaluated. $\beta$-Cayophyllene, $\delta$-cadinene, caryophyllene oxide and germacrene $\mathrm{D}$ were the major constituents. With reference to oil composition, a large difference can be observed comparing to the sample analyzed in Mexico for plants of same genus. However, the composition is similar between different organs of the same plant with few variations, which may be due to the harvest season. About 
Table 4. Antioxidant capacity of the different parts of M. speciosa essential oil.

\begin{tabular}{cc}
\hline Part of Plant & Antioxidant DPPH Capacity \\
\hline Leaves & $72.85 \pm 0.28 \mathrm{mmol} \mathrm{TE} / \mathrm{g}$ essential oil \\
& $147.83 \pm 0.41 \mathrm{mg} / \mathrm{mL} \mathrm{Vit} \mathrm{C/g} \mathrm{essential} \mathrm{oil}$ \\
Flowers & $68.43 \pm 0.10 \mathrm{mmol} \mathrm{TE} / \mathrm{g}$ essential oil \\
& $131.59 \pm 0.87 \mathrm{mg} / \mathrm{mL} \mathrm{Vit} \mathrm{C/g} \mathrm{essential} \mathrm{oil}$ \\
\hline
\end{tabular}

activity antioxidant, the capacity of the leaves essential oil presented an activity slightly higher than the flower essential oil.

\section{References}

[1] Salah, N., Miller, N., Paganga, G. and Tijburg, L. (1995) Polyphenolic Flavanols as Scavengers of Aqueous Phase Radicals and as Chain-Breaking Antioxidants. Archives of Biochemistry and Biophysics, 322, 339-346. https://doi.org/10.1006/abbi.1995.1473

[2] Bravo, L. (1998) Polyphenols: Chemistry, Dietary Sources, Metabolism, and Nutritional Significance. Nutrition Reviews, 56, 317-333. https://doi.org/10.1111/j.1753-4887.1998.tb01670.x

[3] Hayat, K., Zhang, X., Farooq, U., Abbas, S., Xia, S., Jia, C., Zhong, F. and Zhang, J. (2010) Effect of Microwave Treatment on Phenolic Content and Antioxidant Activity of Citrus Mandarin Pomace. Food Chemistry, 123, 423-429. https://doi.org/10.1016/j.foodchem.2010.04.060

[4] Djeridane, A., Yousfi, M., Nadjemi, B., Boutassouna, D., Stocker, P. and Vidal, N. (2006) Antioxidant Activity of Some Algerian Medicinal Plants Extracts Containing Phenolic Compounds. Food Chemistry, 97, 654-660. https://doi.org/10.1016/j.foodchem.2005.04.028

[5] Amarowicz, R., Barl, B. and Pegg, R.B. (1999) Potential Natural Antioxidants from Saskatchewan Indigenous Plants. Journal of Food Lipids, 6, 317-329. https://doi.org/10.1111/j.1745-4522.1999.tb00153.x

[6] Miliauskas, G., Venskutonis, P.R. and Van Beek, T.A. (2004) Screening of Radical Scavenging Activity of Some Medicinal and Aromatic Plant Extracts. Food Chemistry, 85, 231-237. https://doi.org/10.1016/j.foodchem.2003.05.007

[7] Villaseñor, J., Ibarra, G. and Ocaña, D. (1998) Strategies for the Conservation of Asteraceae in Mexico. Conservation Biology, 12, 1066-1075. https://doi.org/10.1046/j.1523-1739.1998.97171.x

[8] Funk, V.A., Bayer, R.J., Keeley, S., Chan, R., Watson, L., Gemeinholzer, B., Schilling, E., Panero, J.L., Baldwin, B.G., Garcia-Jacas, N., Susanna, A. and Jansen, R.K. (2005) Everywhere but Antarctica. Using a Supertree to Understand the Diversity and Distribution of the Compositae. Biologiske Skrifter, 55, 343-374.

[9] Heinrich, M., Robles, M., West, J., Ortiz de Montellano, B. and Rodríguez, E. (1998) Ethnopharmacology of Mexican Asteraceae (Compositae). Annual Review of Pharmacology and Toxicology, 38, 539-565. https://doi.org/10.1146/annurev.pharmtox.38.1.539

[10] Lozoya-Gloria, E. (2003) Chapter Twelve: Xochipilli Updated, Terpenes from Mexican Plants. Recent Advances in Photochemistry, 37, 285-311.

[11] Marrone, J., Cigliano, M. and Crisci, J. (1992) Cladismo y diversidad biológica. Ciencia Hoy, 4, 26-35.

[12] Enriquez, R., Escobedo, C., Recillos, S., Ortiz, B., Villareal, M., Reynolds, W. and Gnecco, D. (2008) Novel Bioactive Compounds from Traditional Medicinal Plants. 
64 th Southwest Regional Meeting of the American Chemical Society, Little Rock, 1-4 October 2008.

[13] Robles-Zepeda, R., Molina-Torres, J., Lozoya-Gloria, E. and López, M. (2006) Volatile Organic Compounds of Leaves and Flowers of Montanoa tomentosa. Flavour and Fragrance Journal, 21, 225-227. https://doi.org/10.1002/ffj.1560

[14] Compadre, C.M., Hussain, R.A., León, I. and Enríquez, R.G. (1987) Volatile Constituents of Montanoa tomentosa and Lippia graveolens. Planta Medica, 53, $495-$ 496. https://doi.org/10.1055/s-2006-962781

[15] Adams, R.P. (2007) Identification of Essential Oil Components by Gas Chromatography/Mass Spectrometry. 4th Edition Allured Publishing Corporation, Carol Stream.

[16] Brand-Williams, W., Cuvelier, M.E. and Berset, C. (1995) Use of a Free Radical Method to Evaluate Antioxidant Activity. Lebensmittel-Wissenschaft \& Technologie, 28, 25-30. https://doi.org/10.1016/S0023-6438(95)80008-5

[17] Matsukawa, R., Dubinsky, Z., Kishimoto, E., Masaki, K., Masuda, Y., Takeuchi, T., Chihara, M., Yamamoto, Y., Niki, E. and Karube, I. (1997) A Comparison of Screening Methods for Antioxidant Activity in Seaweeds. Journal of Applied Phycology, 9, 29-35. https://doi.org/10.1023/A:1007935218120

[18] Yen, G.C. and Duh, P.D. (1994) Scavenging Effect of Methanolic Extracts of Peanut Hulls on Free-Radical and Active-Oxygen Species. Journal of Agricultural and Food Chemistry, 42, 629-632. https://doi.org/10.1021/jf00039a005

[19] Pérez-Amador, M.C., Muñoz, V., Noyola, A. and García-Jiménez, F. (2006) Essential Oil and Phototoxic Compounds in Clibadium surinamense L. and Montanoa grandiflora D. C. Phyton, 75, 145-150.

[20] Vidic, D., Maccksimovic, M., Cavar, S. and Siljak-Yakoviec, S. (2010) Influence of the Continental Climatic Conditions in the Essential-Oil Composition on Salvia Brachyodon Vandas Transferred from Adriatic Coast. Chemistry and Biodiversity, 7, 1208-1216. https://doi.org/10.1002/cbdv.200900126

[21] Trejo, R., Gaytán, A., Mendoza, D. and Sabanero, M. (1996) 3-Hydroxyencelin: Synthesis and in Vitro Activity. Microbios, 88, 97-104.

[22] Sabanero, M., Quijano, L., Rios, T. and Trejo, R. (1995) Encelin: A Fungal Growth Inhibitor. Planta Medica, 61, 185-186. https://doi.org/10.1055/s-2006-958046

[23] Quijano, L., Gomez-Garibay, F., Trejo, R. and Rios, T. (1991) Hydroxy-Bis-Dihydroencelin, a Dimeric Eudesmanolide and Other Eudesmanolides from Montanoa speciosa. Phytochemistry, 30, 3293-3295.

https://doi.org/10.1016/0031-9422(91)83196-R 
Submit or recommend next manuscript to SCIRP and we will provide best service for you:

Accepting pre-submission inquiries through Email, Facebook, LinkedIn, Twitter, etc. A wide selection of journals (inclusive of 9 subjects, more than 200 journals)

Providing 24-hour high-quality service

User-friendly online submission system

Fair and swift peer-review system

Efficient typesetting and proofreading procedure

Display of the result of downloads and visits, as well as the number of cited articles Maximum dissemination of your research work

Submit your manuscript at: http://papersubmission.scirp.org/

Or contact ajps@scirp.org 